\title{
Spojrzenie człowieka na Boga Ojca w Pieśniach sobie śpiewanych Konstancji Benisławskiej na podstawie leksyki określającej ojca*
}

\author{
A human view on God the Father in Pieśni sobie śpiewane \\ (Songs sung for oneself) written by Konstancja Benisławska, \\ based on vocabulary related to the word 'father'
}

\author{
Joanna Gorzelana \\ Wydział Humanistyczny, Uniwersytet Zielonogórski, \\ ul. Licealna 9, 65-001 Zielona Góra, Polska; \\ e-mail: ].Gorzelana@ifp.uz.zgora.pl
}

\begin{abstract}
Abstrakt
Celem pracy jest przedstawienie określeń odnoszących się do Boga Ojca w wierszach religijnych Konstancji Benisławskiej. Pieśni sobie śpiewane opublikowane w oświeceniu (1776 r.) zawierają wiele struktur wskazujących na to, jak poetka wyobraża sobie Boga. Charakterystyczne połączenia wskazują na jego dobroć i potęgę: Ojciec nasz, Ojciec jedyny, Ojciec łaskawy, Ojciec wszechmogacy, Ojciec przedziwny, Ojciec mily i Ojciec dobry. Obecne są też elementy antropomorficzne (ręka Ojca, twarz Ojca), a także wyrażenie związane z dogmatem trynitarnym przekonują, że Bóg Ojciec jest osobą Trójcy Świętej.
\end{abstract}

Słowa kluczowe: liryka oświecenia; obraz Boga; leksyka religijna.

\begin{abstract}
The aim of this study is to present the expressions referring to God the Father in the religious poems of Konstancja Benisławska. Pieśni sobie śpiewane (Eng. Songs sung for oneself) published during the Enlightenment (1776) contain many structures showing how the poet perceived God. Characteristic combinations indicate his goodness and power: our father, our only father, our gracious father, our almightily father, our wonderful father, nice and good father. [Ojciec nasz, Ojciec jedyny, Ojciec taskawy, Ojciec wszechmogacy, Ojciec przedziwny, Ojciec mity i Ojciec dobry]. There are also anthropomorphic elements (father's hand, father's face [ręka Ojca, twarz Ojca ]) and an expression associated with the dogma of the Trinity which corroborate an opinion that God the Father is a person of the Trinity.
\end{abstract}

Keywords: poems in the Enlightenment; image of God; religious poems.

Konstancja Benisławska (1747-1806) opublikowała ,za naleganiem przyjaciół” w Wilnie 1776 roku jedyny swój tomik wierszy zatytułowany Pieśni sobie

* Tekst ten został zaprezentowany podczas konferencji Język religijny dawniej i dziś (w kontekście teologicznym i kulturowym), która odbyła się w Paradyżu (17-19 września 2012 r.). 
śpiewane. Zbiór ten zawiera lirykę religijną, która jest rozmową z Bogiem, przeplataną refleksją nad wiarą i kondycją człowieka. Tomik zbudowany został $\mathrm{z}$ trzech zasadniczych części ${ }^{1}$ : pierwszą stanowi cykl Modlitwa Pańska na pieśni rozłożona; w drugiej znajdują się utwory pod wspólnym tytułem Pozdrowienie Anielskie na pieśni rozłożone, zaś Księga trzecia zawiera zbiór 24 pieśni o tematyce błagalnej i pochwalnej. Celem artykułu jest przedstawienie tego, w jaki sposób poetka kreuje obraz Boga - Ojca.

Leksem ojciec (ociec) w tomiku 140 razy odnosi się do Boga, z tego pięciokrotnie występuje w tytułach pieśni, rzadko wskazuje na człowieka (15 razy)². Dominuje więc użycie konotujące osobę Boga, określając ją w różny sposób.

Na początku cyklu - w pierwszej pieśni - pojawia się uzasadnienie stosowania przez podmiot nazwy ojciec w odniesieniu do Boga:

Z tym wszystkim, Panie, nigdy bym, jak żywię,

Ojcem zwać Ciebie nie śmiała prawdziwie

By Syn rodzony Twój Ojcem jedynie

Zwać nie nakazał nędznej człowieczynie (I 1/9-12)3.

Podmiot odwołuje się do autorytetu Chrystusa, przypominając, iż to właśnie Boży Syn zalecił ludziom nazywać Boga słowem ojciec. Można powiedzieć, że, z jednej strony, status „synów Bożych” ludzie zyskują dzięki Jezusowi (Gomola 2009: 208). Podmiot nawiązuje do wydarzenia opisanego w Ewangelii (por. Mt 6, $8 \mathrm{~b}-9)^{4}$. Z drugiej jednak strony człowiek ma świadomość swojej małości, nazywając siebie leksemem człowieczyna, wskazuje na małą wartość i pewne lekceważenie (por. Gorzelana 2011: 293). Podmiot formułuje nawet pytanie retoryczne dotyczące „myśli” czy też przyzwolenia Boga na taką formę adresatywną pochodzącą od człowieka:

Co na to myślisz, gdy lepianka licha

Ojcem Cię zowie, jak do Ojca wzdycha? (I 1/3-4).

Rzeczownik lepianka, jakim tutaj określa siebie podmiot, oznaczać ma to, co zostało ulepione - stworzone przez Boga z ziemi $(\operatorname{Rdz} 2,7)^{5}$, natomiast Bóg jest

${ }^{1} \mathrm{Na}$ wstępie umieszczono 4 anonimowe wiersze dedykacyjne, a w części oryginalnej przed zasadniczym cyklem jest jeszcze Pieśn przed zaczęciem abo zachwyt ducha do Ducha Najświętszego i Pieśń przeżegnania o funkcji egzorcyzmu.

2 Jedno użycie w odniesieniu do szatana: „Wy sąście z ojca diabła, diabła przeklętego!” (I 2/56).

${ }^{3} \mathrm{~W}$ tekście zastosowano dla określenia lokalizacji cyfrę rzymską na oznaczenie numeru księgi jak w wydaniu K. Benisławska (1776); pierwszą cyfrę arabską na oznaczenie kolejnego utworu w księdze, a kolejne na oznaczenie wersów; PP - pieśń przeżegnania, poza numeracją.

${ }^{4}$ Wszystkie odniesienia do Biblii i cytaty podaję za Biblia w przekładzie Jakuba Wujka z 1599 r. (1999).

${ }^{5}$ Na temat określeń podmiotu w tych pieśniach por. Chachulski 1995: 84. 
tym, którego człowiek nazywa ojcem i do którego wzdycha - zawarte pytanie przedstawia tęsknotę jako relację człowieka względem Boga.

Rzeczownik ojciec w tomiku Benisławskiej użyty jest w funkcji określania Pierwszej Osoby Boga. Pojawiają się tam również połączenia Bóg Ojciec (5 razy) najczęściej w linearnym sąsiedztwie określeń Drugiej i Trzeciej Osoby Boskiej. Przykładowo w rozbudowanej apostrofie do Boga Ojca, Boga Syna i Boga Ducha, gdzie odwołanie do całej Trójcy Świętej określanej szczegółowo pełni funkcję szczególnie uroczystej formuły:

Boże Ojcze, niech Twe Imię

Pod straż swoję rozum przyjmie!

Boże Synu, strzeż pamięci!

Boże Duchu, strzeż mych chęci! (PP 17-20).

Apostrofa powyższa występuje w Pieśni przeżegnania otwierającej cykl poetycki autorki ${ }^{6}$ i pełni funkcję prośby o pomoc i opiekę. Podobne prośby skierowane są do Maryi, aby ona wypraszała łaski Boga $\mathrm{z}$ odwoływaniem się do wszystkich Osób Trójcy Świętej:

Módl się do Boga Ojca Niebieskiego!

Módl się do Syna i Ducha Świętego! [...]

Módl się, proś Boga, o Matko jedyna!

Ojca przez Syna, a przez Ojca Syna,

Ducha Świętego przez Syna i Ojca!

Módl się, niech przyjmie nas Najświętsza Trójca! (II 9/97-98. 105-108).

Powyższe prośby pochodzą z Pieśni zatytułowanej Módl się za nami grzesznymi teraz $i$ w godzinę śmierci naszej! Amen. Wskazują pośrednio na to, że każda osoba Boska może pośredniczyć w przekazywaniu prośby u pozostałych Boskich Osób. Są one sobie równe, określane rzeczownikiem Trójca opatrzonym przydawką w formie superlatywnej najświętsza. W tym wezwaniu podkreślona zostaje równość Osób Boskich, podobnie jak w poniższym fragmencie, w którym mowa o jedności istoty osób Trójcy:

Ojcze nasz! Kto? Ty, Boże! Tyś jest nam za Ojca!

Jeden w istocie, w liczbie niepodzielna Trójca (I 2/9-10).

Cała Trójca towarzyszyła także przyjściu na ziemię Zbawiciela, podkreślone zostały różne cechy poszczególnych osób:

Ziemia otwarta dała Zbawiciela!

W tę pieśn wchodziła cała święta Trójca,

${ }^{6} \mathrm{~W}$ tomiku Benisławskiej zamieszczono na wstępie 4 wiersze dedykacyjne innego autorstwa, nie są one przedmiotem niniejszej analizy.

${ }^{7}$ Podane tu informacje są zgodne z nauką Kościoła - por. KKK 1994: 69, 70-71 (NR 254 in.). 
Powaga w Posła wysyłaniu Ojca,

Mądrość wcielić się mającego Słowa

I pomoc Ducha Świętego gotowa! (III 23/12-16).

Z powyższego fragmentu wynika, że - zdaniem poetki - Boga Ojca znamionuje powaga. Wydaje się, że na taką charakterystykę miało wpływ ludzkie patriarchalne postrzeganie ojca, tradycyjnie pojmowanej głowy rodziny. Obraz Boga Ojca, jako jednej z osób Trójcy obecny jest także w kontekście poczęcia Maryi:

Syn Boży z Tobą, któregoś objęła,

Duch Święty z Tobą, z któregoś poczęła,

Bóg Ociec z Tobą, za najmilszą, który

Przybrał Cię Córkę z wszelkiej kreatury (II 4/5-8).

Maryja, jako osoba wybrana przez Trójcę, także określana jest przez wyrażenia wskazujące na osoby Syna Boga, Ducha Najświętszego i Boga Ojca:

Zdrowaś, Maryja! Miasto Syna Boga!

Łożnico Ducha Najświętszego droga!

Żywy Portrecie Twarzy Boga Ojca!

Przez Cię dała się światu poznać Trójca (II 1/105-108).

Określenie żywy portret Twarzy Boga Ojca, będąc peryfrazą osoby Maryi, informuje pośrednio o antropomorficznym ujmowaniu Boga - w jego opisie pojawia się leksem twarz.

Pierwotność Boga w ujęciu czasowym wyraża przymiotnik przedwieczny, np.:

Ojcze nasz! O Przedwieczny Boże Ojcze (I 2/193);

Tego Ociec Przedwieczny, co mieszka na niebie,

Za syna kochanego przybiera dla siebie (III 5/5-6);

Przedwieczny Synu Ojca Przedwiecznego,

Jezu łaskaw, miłosierny Panie! (III 6/1-2).

W ostatnim przykładzie - apostrofie do Jezusa wyrażona została jego ponadczasowość przez analogię do ponadczasowości Boga Ojca, która jest tu wyrażone a priori. Autorka - przez powtórzenie - podkreśla ową analogię. Niekiedy pojawia się deklaracja równej postawy podmiotu lirycznego względem całej Trójcy Świętej. Przykładowo w poniższym przykładzie podmiot prosi o możliwość przebywania w niebie, aby tam chwalić Boga:

Bym dostąiłia wiecznej swobody Niebianów,

Gdzie bym ci, Jezu, Ojcze i Duchu Przedwieczny,

Brzmiała hymn wieczny! (III 11/27-28). 
O tym, że podmiot pragnie śpiewać hymn Bogu w Trójcy, świadczy nie tylko wyliczenie nazw Boskich Osób, ale przede wszystkim zastosowanie środka stylistycznego, jakim jest zeugma. W powyższym fragmencie zwrot bym brzmiała hymn odnosi się do wszystkich rzeczowników nazywających poszczególne Osoby Boskie. Podobnie zastosowano zeugme w popularnej do dziś konstrukcji znajdującej się w pieśni zamykającej tomik Pieśń ostatnia. Chwała Ojcu i Synowi etc.

Chwała bądź Bogu we trzech jedynemu,

Ojcu, Synowi, Duchowi Świętemu! (III 24/5-6).

Interesujący sposób ujęcia jedności natury jawi się w poniższym obrazie charakteryzującym Drugą Osobę Boską:

Jeśli chcesz kochać - Jezus Ociec mily, [...]

Chcesz być bogatym - Jezus skarb prawdziwy! (II 6/45-48).

Boska natura Jezusa przejawia się więc w tym, że staje się on wszystkim, także ojcem, jeśli tego potrzebuje człowiek. W interesującym cyklu poetyckim spotykamy również nakładanie się obrazu Boga Ojca - jednej z osób Bożych z obrazem Boga - ojca ludzi. Przykładowo, prosząc Maryję o pośredniczenie, podmiot odwołuje się do relacji, jakie wiążą ją z poszczególnymi Osobami Trójcy:

Ojca skłoń, Córko, pokorą niewinną,

Syna nam zniewol powagą Matczyną,

Ducha Świętego miłości Twej mocą (II 9/109-111).

Wskazanie na wieź między ojcem a córką informuje pośrednio o powszechnym ojcostwie Boga względem do ludzi. Relacja między Maryją a Bogiem nie jest łatwa do przedstawienia. Przyjmując jedność osób Boskich, dochodzi bowiem do paradoksu:

Matko Boga! Tyś prawdziwą Matką

Ojca wlasnego! O dziwna zagadko!

Prawdziwy Ociec przecudownym czynem

Staje się Córki Swej prawdziwym Synem! (II 8/9-12).

Pojawiające się tu określenie dziwna zagadka wskazywać mogło w XVIII wieku na nadprzyrodzoność i oficjalność ${ }^{8}$. Użyty przymiotnik prawdziwy - określający

${ }^{8}$ Linde definiuje zagadkę: 'co się zadaje komu do rozwiązania', podając przykłady użycia z Psałterza i kazań; (SL, t. 6: 750-751); natomiast znaczenia przymiotnika dziwny podaje w następującej kolejności: 1. 'zadziwiający’ 2. 'nadprzyrodzony', 3 ‘dziwacki, dziwaczny’ (SL, t. 1: 620). 
ojca - został derywowany od rzeczownika prawda i służy podkreśleniu tego, że podmiot przyjmuje i akceptuje istnienia tego paradoksu?

Wśród innych epitetów opisujących leksem ojciec najczęściej (7 razy) spotykamy przymiotnik jedyny, który podkreśla niepowtarzalność Bożego ojcostwa i jego wyłączność. Przykłady użycia wyrażenie jedyny Ojciec odnoszą się do jego Boskich możliwości, może on odpuszczać grzechy i obdarzać łaskami oraz żywić, np.:

Tak odpuść wszelkie grzechy nam, Ojcze jedyny! (III 22/20);

Strach duszę mą zabija, Ty, Ojeze jedyny,

Bez końca miłosierny, odpuść nasze winy! (I 7/3-4);

Nie ujmuj mi skutecznych łask, Ojcze jedyny! (I 8/82).

Wyrażenie ojciec jedyny poetka umieszcza też w kontekście prośby o chleb powszedni. Bóg jawi się jako ojciec, który troszczy się o pokarm dla swoich dzieci - wszystkich ludzi. W fragmentach obecne są bowiem zaimki liczby mnogiej: (dzierżawczy) nasz i (osobowy) my, także w prośbie wyrażonej przez podmiot indywidualny (konotowany formą czasownika):

Równie wszytkich Ty żywisz, Ojcze nasz jedyny (I 2/45);

Daj nam chleba naszego! Wiem, Ojcze jedyny,

Żem niegodna do stołu z Twymi siadać syny, [...]

Daj nam chleba naszego, Ojcze wszechmogący! (I 6/41-42,53).

Ostatni przykład pochodzący z pieśni zatytułowanej Daj nam chleba naszego powszedniego dzisiaj nawiązuje do ewangelijnego obrazu syna marnotrawnego (Łk 15,11-32). Epitet wszechmogący wskazuje na potęgę Boga, odwołanie do tej cechy jest argumentem, uzasadniającym prośbę człowieka. Do obowiązków ojcowskich, które wynikają z przyrodzenia ${ }^{10}$, zaliczyć można także troskę o przyodziewek dzieci:

Ojcze! Pomni, żeś Ojcem nad duszy gołotą,

Charłaczki mej, pożal się, a przyoblecz cnotą!

Wszakci to z przyrodzenia ojcowi należy

Córce nagiej dostarczyć potrzebnej odzieży (I 2/181-184).

${ }^{9}$ Paradoks często jest wykorzystywany w tekstach mistyków (por. Rutkowska 2005: 518-527).

${ }^{10}$ Linde podaje: przyrodzenie 'natura' (SL, t. 4: 677). 
Znamienne jest, że prośba dotyczy sfery duchowej, nie materialnej, podmiot prosi bowiem o łaski dla duszy. W innej części tej samej pieśni (Ojcze nasz, któryś jest w niebie) podmiot, odwołując się do Bożego ojcostwa i wynikającego z tego dziecięctwa Bożego, prosi o dziedzictwo. Największym bogactwem, jakie może otrzymać człowiek, jest sam Bóg:

Ojcze nasz! Tyś mym Ojcem! Toć ja Twoja córa!

Dajże mi moję cząstkę, spada na mię która! [...]

Jeżeli masz co, Panie, dać mi w mej potrzebie,

Wszystko weź i zatrzymaj, a daj tylko Siebie (I 2/33-34,37-38).

Bycie dzieckiem Boga podmiot przyjmuje z radością, ma bowiem świadomość wieczności tego dziecięctwa:

Ojcze nasz! Ojcze wieczny! O, jakie wesele!

To i ja wieczną córką Twą się nazwę śmiele,

Bo nikt z Twego Ojcowstwa mię wyzuć nie może (I 2/61-63);

Ojcze nasz! Ach, jak wielką córką mię zdziałałeś (I 2/201).

Podmiot przytacza słowa Boga, w których, zwracając się do człowieka, mówi także o wynikających z tych relacji obowiązków dziecka względem ojca:

„Jeżelim Ja twój Ociec, gdzież, o córko Moja,

Ku Mnie poszanowanie winne i cześć twoja?"

Ach, daruj, Ojcze, winę! Twa dobroć zgniewana (I 2/115-117).

Wypowiedzi tej towarzyszy prośba podmiotu o darowanie przewinień względem niego i świadomość własnej niedoskonałości, która kontrastuje z dobrocią Boga Ojca:

Ojcze nasz, o mój Ojcze! Taką w każdej dobie

$Z$ całej duszy i serca chcę być córką Tobie,

Jakim Tyś mi jest Ojcem. Ale któż być może

Tak dobrym dzieckiem, jak Tyś dobrym Ojcem, Boże? (I 2/125-128).

Świadoma własnych słabości prosi bohaterka o łaski, które wypływać mogą tylko od Boga nazwanego peryfrastycznie Ojcem lask:

Ojcze nasz! Ojcze laski, chwały nieprzystępnej!

Uczyń mię córką łaski i chwały następnej!

Ojcze mądrości, uczyń córką mię mądrości!

Ojcze wszech wieków, córką uczyń w Twej wieczności! (I 2/261-263). 
Spotykamy się także z interesującym zabiegiem perswazyjnym ${ }^{11}$. Otóż jako uzasadnienie prośby do Boga Ojca pojawia się informacja o tym, że brak jego darów jest przyczyną złego zachowania człowieka, który zasmuca Ojca i powoduje jego gniew:

Ojcze nasz! Spraw, bym córką głupią ja nie była,

Która zasmuca Ojca kochanego siła! (I 2/57-58).

Pojawiająca się w tym obrazie przydawka kochany wskazuje na miłość jako cechę prymarną Boga Ojca. Podobnie w innym fragmencie podmiot zwraca uwagę, że wystarczy najmniejszy przejaw żalu - byle tezka, aby Bóg, kierujący się litością, zapomniał o tym, co dziatki pobroiły ${ }^{12}$ :

Ojcze! Bo byle łezka, wnet Twa litość święta

Na pobrojenie rzewnych dziatek nie pamięta (I 2/145-146).

Odwołując się do metod wychowawczych stosowanych przez ziemskich rodziców (w XVIII w.), podmiot wprowadza obraz karanie ludzi rózgą przez Boga Ojca:

Ojcze nasz! Ojcze wszystkich! Ojcze, któryś w niebie!

I z rózgi na tym świecie chcę znać Ojcem Ciebie!

Karz moje tu swawole, zacinaj po grzbiecie!

Zacinane przychodzi do rozumu dziecię (I 2/149-152);

Do poznania rodziców pędzi rózga dzieci.

Ojcze nasz! Bo choć ręka Twa nas dobrze otnie,

Potem nas po ojcowsku głaszczesz postokrotnie.

Nigdyś nie zły do końca. Sieczże mię tu, Panie,

Bym zasłużyła na Twe wieczne poglaskanie!

W rózdze i pogłaskaniu, w zdrowiu i chorobie!

Bo lub glaszczesz lub sieczesz, wszystko czynisz na to,

Ażebyś mię uczynił dziedziczką bogatą (I 2/160-168).

Podmiot podkreśla cel kary, jakim jest nauka oraz zwraca uwagę na to, że po skarceniu Ojciec łagodzi zadane cierpienie, gdyż jego ojcostwo cechuje ciepło i życzliwość. Obecne konstrukcje: głaskać postokrotnie, wieczne pogłaskanie zawierają leksykalne wyznaczniki wskazujące na ogrom ojcowskiej czułości.

W innym obrazie podmiot pisze o Twarzy Ojca, przed którą chce stanąć. Stawanie przed twarzą zawsze wskazuje na bliskość, a kontekst użycia mówi o pragnieniu wiecznego przebywania przed Bogiem:

\footnotetext{
${ }^{11}$ Perswazyjność jest jedną z cech tekstów religijnych (por. Gorzelana 2006: 190-218).

${ }^{12}$ Na temat funkcji zdrobnienia w tym obrazie zob. Gorzelana 2011: 301.
} 
Żądam, o Ojcze, stanąc przed Twą twarzą

I żyć w rozkoszy z Tobą wiecznotrwałej! (III 19/11-12).

Dodać w tym miejscu należy, iż leksem żądać w oświeceniowym Słowniku języka polskiego S.B. Lindego posiadł podstawowe znaczenie 'tęskliwie wyglądać czego' ${ }^{13}$. Autorka na określenie owego czasu przebywania użyła niecodziennej formy złożonej wiecznotrwały. Przymiotnik ten zbudowany z dwu przymiotników wskazujących na ponadczasowość (wieczny, trwały) intensyfikuje tę treść i ją podkreśla.

Bóg Ojciec przewyższa innych ojców, mówi o tym apostrofa do Boga wyrażona peryfrazą ojcze nad wszystkie ojce, która w tekście pojawia się pięciokrotnie w funkcji anafory. Przykładowo w poniższym fragmencie podkreślona została ponadczasowość bożego ojcostwa, które jest praprzyczyną ludzkich zależności:

Ojcze nad wszystkie ojce! Abowiem od Ciebie

Wszelakie jest ojcostwo na ziemi i niebie,

Boś Ty Ojcem od wieków do wieków, mój Panie!

Innych ojcostwo w czasie i z czasem ustanie (I 2/213-216).

Uzasadnieniem wyższości ojcostwa Boga nad ojcostwem ludzkim jest to, że od Boga pochodzi nieśmiertelna dusza, określona przez podmiot jako czastka najszlachetniejsza człowieka:

Ojeze nad wszystkie ojce! Bo duszy niedzielnej

Sam jeden Ojcem jesteś, duszy nieśmiertelnej -

Cząstki najszlachetniejszej, której ni od matki,

Ani od ojców mogą wziąć cielesnych dziatki (I 2/217-220).

Poetka zwraca uwagę, że także powstanie ludzkiego ciała uzależnione jest od Bożego błogosławieństwa, określonego tu czasownikiem przeżegnać. Również niepoznany do końca przez człowieka rozwój prenatalny, dla Boga - Ojca nie jest tajemnicą, gdyż posiada on wiedzę dotyczącą dziecka, która przewyższa wiedzę biologicznych rodziców. Tylko Bóg Ojciec wie, jak rozwija się człowiek:

Ojcze nad wszystkie ojce! Bo żeśmy i ciało

Od swych rodziców wzięli, z Twej się woli stało,

Ponieważ nie jest w mocy to ojca i matki,

Kiedy Ty nie przeżegnasz, mieć po sobie dziatki. [...]

Ojcze nad ojce, matki! Nie wiedzą macierze,

Jako się w ich żywocie człowiek tam przybierze (I 2/225-228, 230).

${ }^{13}$ Natomiast jako kolejne znaczenie opatrzone gwiazdką (czyli dawne, niespotykane, podejrzane) jest w słowniku *'prosić, osobliwie z naleganiem, usilnie, suplikować' (SL, t. 6: 735-736). 
Wielkość Boga wypływa także z jego dobroci przewyższającej dobroć ziemskich rodziców względem swoich dzieci.

Ojcze nad wszystkie ojce! Gotowam to przysiąc:

Ojcze nad wszystkie matki lepszy razy tysiąc!

Ojcze, po stokroć Ojcze! Ojcze, któryś w niebie! (I 2/241-243).

W ostatnim przykładzie górowanie Boga nad ludźmi wyrażone zostało formalnie (przez użycie przyimka nad) i leksykalnie wskazując na niebo, jako siedzibę królewską i miejsce jego panowania:

Ojcze nasz, któryś jest w niebie jak król na stolicy (I 2/1).

Przebywanie w niebie nie wyklucza jednak znajomości ziemi. Bóg przenika bowiem całą sferę, niebo staje się tu synonimem Boskich możliwości przebywania w całej przestrzeni, co wyraża poniższa doksologia:

Ojcze nasz, któryś w niebie! Tyś i z wszech pożytkiem

Nad wszytkim i pod wszytkim, przed wszytkim, we wszytkiem (I /17-18).

Pojawiający się w wierszach rzeczownik niebiosa jest podstawą derywatu niebieski $i^{14}$, który pełni funkcje epitetu określającego rzeczownik ojciec:

Bowiem Ociec Niebieski z jasnego pałaca

Ciemne widzi skrytości i wskróś serca maca! (III 22/5-6).

Wskazując na Boga, mieszkającego w niebiosach, podmiot określa go przymiotnikiem w stopniu najwyższym najkochańszy i nazywa go dobrym:

Ojcze najkochańszy, co stolicę drogą

Osiadłszy górnych niebios depcesz gwiazdy nogą (III 22/9-10);

Ojcze! O Ojcze dobry! Ojcze, któryś w niebie! (I 2/29).

To właśnie dobroć Ojca wyrażoną przymiotnikiem dobry sprawia, że człowiek pokłada w nim nadzieję:

Ale, dobry nasz Ojcze, w Tobie mam nadzieję (I 9/13).

Dobroć jest cechą, która łączy się z łaskawością, stąd w bliskim sąsiedztwie pojawiają się epitety dobry i łaskawy:

Ojcze nasz! Ojcze dobry! O Ojcze laskawy! (I 2/133).

${ }^{14}$ Dodać należy, iż w XVIII wieku podstawowe znaczenie przymiotnika niebieski to - zgodnie ze słownikiem Lindego: 'od nieba, nieba się tyczący' (SL, t. 3: 3128). Natomiast odniesienie do koloru słownik podaje jako drugie, por. też: Zaręba 1956: 45. 
Do łaskawości ojcowskiej odwołuje się zaś podmiot w apostrofie do Boga Sędziego i mściciela, przypominając przez użycie wyrażenia ojcze łaskawy o jego miłosierdziu:

Sędzio świata ogromny i prawy,

Mścicielu srogi i Ojcze laskawy! (III 21/3-4).

Podobnie w poniższym fragmencie, zwracając się do sprawiedliwego Boga, podmiot stosuje wyrażenie Ojcze litościwy:

A Ty, o Boże, Boże sprawiedliwy,

A razem Ojcze, Ojcze litościwy (III 2/5-6).

Rzeczownik ojciec stosunkowo często (7 razy) określany jest epitetem mity, co wyrażać może pewną zażyłość i familiarność ${ }^{15}$, towarzyszą jej często leksemy wskazujące na uczucia (zapłakać, kochać), np.:

Ojcze nasz, Ojcze mily! Ach, jako zapłaczę (I 2/65);

Ojcze nasz, mily Ojcze! Więc obym Cię po wiek

Wszytek mój tak kochała odtąd, jakom człowiek! (I 2/81-82).

Leksem miły obok formy laskawy pojawia się także w kontekście grzechu:

Cóż już jakoś jest dobry, jak laskawy Ociec

Dla tych, co Cię szukają, któż potrafi dociec?

Jednak, ach, jako wiele, o Ojcze nasz mily,

Swawolnych dziatek, które Ciebie odstąpiły (I 2/103-106);

Bo nikogo nie kusisz na złe. Ojcze mily,

Lecz nie daj duszołowcom kusić mię nad siły (I 8/3-4).

Drugi przykład pochodzi z parafrazy zdania z modlitwy Pańskiej (Nie wódź nas na pokuszenie) i jest rozwinięciem myśli o szatańskim pochodzeniu pokus ${ }^{16}$. Podmiot, mając świadomość tego, że zasłużył na gniew Boga Ojca, pisze równocześnie o swej nieustannej miłości do Niego, która nie może wygasnąć ze względu na to, iż Bóg ze swej natury jest mity ${ }^{17}$.

${ }^{15}$ Forma miły w wierszach Benisławskiej określa też Maryję - Matkę Bożą i Jezusa - Bożego Syna. Dodać należy, iż w połączeniu z rzeczownikiem Bóg epitet mity występuje dwukrotnie - tylko w kontekście Bożej córki i Jezusa.

${ }^{16} \mathrm{Na}$ temat leksemu duszołowca por. Gorzelana 2012: 111.

${ }^{17}$ Linde podaje: mity 'przyjemny, wdzięczny, 2 kochany, 3 miły komu, od niego kochany' (SL, t. 3: 118) 
Ojcze! Chociaż się gniewu Twego stracham więcej

Niż w gniewie Twym zażgniętych piekłów sto tysięcy,

Przecież, byś mię i zhydził, ja Cię z całej siły

Nie, nie przestanę kochać, boś Ty w Sobie mily (I 2/257-260).

Dobroci Boga towarzyszy jego wielkość, która jest atrybutem jego ojcostwa:

Ach, jak wielki nasz Ojcze! Cóż mógł człek takiego

Zadziałać, by Ojcowstwa był wart tak wielkiego! (I 2/25-26).

Konsekwentnie - z wielkości Boga wynika wielkość jego ojcostwa. Ojcostwo to kojarzone jest z uczuciem miłości - obecne są wyrażenia miłość ojcowska:

Za chleb i sól dziękując, za miłość Ojcowską (I 2/107);

Tak nie jest - wiem, o Ojcze - syn synem, jeżeli

Od milości ojcowskiej sercem się oddzieli (I 2/53-54).

Poetka zwraca przy tym uwagę na to, że człowiek sam może dobrowolnie odciąć się od tej miłości, wyrzekając się Bożego Ojcostwa. W tym kontekście pojawiają się czasowniki oddzielić się (od czego), zrzec się (czego):

Ojcze! Któż się nie zdziwi? Człek bez winy Twojej

Zrzec się Twego Ojcostwa ma w wolności swojej (I 2/121-122);

Bo choć człek często Twego Ojcostwa się zrzeka,

Ty jednak chcesz być zawsze Ojcem dla człowieka (I 2/129-130).

Bóg obdarza człowieka wolnością także w przyjęciu jego dziecięctwa, chociaż sam, jak głosi podmiot, nigdy z człowieka nie zrezygnuje, ,zawsze chce” być jego ojcem. Argumentem przemawiającym za tą tezą, ma być ukształtowanie człowieka na Boskie podobieństwo:

Ojcze! Bo żeś sam Ojcem chciał mi być od wieka,

Przetoś na podobieństwo Twe stworzył człowieka (I 2/209-210).

Z przypomnieniem owego podobieństwa wiązać można antropocentryczne ujmowanie Boga, które jest częste w poezji religijnej. Sam Bóg - Ojciec jest ponad czasem $^{18}$, wskazują na ten fakt wyrażenia od wieka i w każdej dobie:

Ojcze! Bo żeś sam Ojcem chciał mi być od wieka,

Przetoś na podobieństwo Twe stworzył człowieka (I 2/209-210);

Ojcze nasz! Ojcze wszędzie, Ojcze w każdej dobie (I 2/165);

„Ojcze nasz” - to czci Imię, Imię władzy stałej (I 2/73).

18 „A wszyscy zgoła osiadają w niebie/ Na wieki wieków współ z Tobą przez Ciebie” (II 3/211-212). 
Ostatni z podanych przykładów wskazuje także na ponadczasowość władzy rodzicielskiej, która nie ma ani początku ani końca, jest stała. Ojcostwo Boga łączy się z macierzyństwem Kościoła, podmiot bowiem zgodnie z tradycją nazywa Kościół - Matką (mater Ecclesia):

Ojcze! Abowiem, innych odrzuciwszy wiele,

Tyś mię w wszech wiernych Matce urodził, Kościele,

Która mi daje poznać Ciebie, Ojca mego (I 2/185-187).

W Kościele przez sakramenty Bóg obdarza człowieka życiem, o ile życie fizyczne jest jednokrotne, chociaż też otrzymane od Boga, co symbolizuje biblijna glina ${ }^{19}$, o tyle życie duchowe może być wciąż odnawiane:

Ojcze! Bo z Twych rąk sąśmy już z kości, już z gliny.

Gdyśmy zmarli, Ty-ś drugie dał życie przez chrzciny.

Gdyśmy po trzecie zmarli, Tyś dał życie trzecie

Przez pokutę nam świętą pozwoloną w świecie (I 2/169-172).

Sakramenty chrztu i pokuty dają nowe życie duchowe, które otrzymuje człowiek od Boga Ojca za pośrednictwem Kościoła.

Podsumowując, należy zauważyć, że w tomiku Pieśni sobie śpiewanych Konstancji Benisławskiej leksem ojciec pełni funkcję słowa klucza, występując 156 razy. Leksem ten najczęściej wskazuje na Boga - Ojca, który jest osobą Bożą przedstawianą w kontekście pozostałych osób Trójcy. Ujmowany jest też niezależnie od innych osób, często antropocentrycznie.

Leksem ojciec tworzy następujące wyrażenia: Bóg Ojciec (5 razy), przedziwny Bóg Ojciec, Ojciec madrości i Ojciec łask, oraz analogiczne do ostatniego wyrażenie z przydawką przymiotnikową: Ojciec laskawy (2 razy). Dwukrotnie występują też nazwy: Ojciec wszechmogacy, Ojciec przedziwny, Ojciec mily i Ojciec dobry - ostatnie połączenia pojawiają się ponadto w przestawionym szyku mity Ojciec (2 razy) i dobry Ojciec. Zmiany szyku przydawki widoczne są w określeniach zaimkowych, gdyż spotykamy zarówno formy Ojciec nasz (30 razy), Ojciec nasz jedyny (1 raz), Ojciec nasz miły, jak również nasz Ojciec (1 raz) oraz dobry nasz Ojciec (1 raz) i analogicznie Ojciec mój (2 razy) i mój Ojciec (1 raz).

Wśród innych wyrażeń obecne są struktury wskazujące na uczucia podmiotu względem Boga: Ojciec kochany i Ojciec najukochańszy (pochodzące od czasownika kochać) Ojciec litościwy (1 raz). O ponadczasowości i powszechności Bożego ojcostwa zdają się natomiast świadczyć połączenia Ojciec wieczny i Ojciec wszech wieków oraz Ojciec wszystkich (1 raz), Ojciec powszechny (1 raz), Ojciec jedyny (6 razy). To ostatnie wyrażenie służy podkreśleniu wyjątkowości Bożego ojcostwa, które jest autentyczne i niepowtarzalne. Natomiast połączenie Ojciec

${ }^{19}$ Obraz pochodzenia z kości też jest proweniencji biblijnej (por. Rdz. 2,21-23). 
niebieski wskazuje pośrednio na nadprzyrodzony charakter ojcostwa, łącząc je z niebem.

Dodać należy, iż pojawiają się także wyrażenia wskazujące na postrzeganie Boga podobnego do człowieka: ręka ojcowska, twarz ojca, oraz zwroty analogiczne do nazw czynności wykonywanych przez ziemskich rodziców: siec rózga, pogłaskiwać.

Cały cykl poetycki jest zbiorem modlitw odzwierciedlających rozmowę podmiotu lirycznego z Bogiem, dlatego najczęściej, bo aż 98 razy, leksem ojciec występuje w formie wołacza, co podkreśla strukturę dialogową (Pawlikowska 2013: 60), bezpośrednie zwracanie się do odbiorcy - Boga, traktowanego z szacunkiem, ale i w sposób bezpośredni, tak jak ojca ziemskiego.

\section{Bibliografia}

Benisławska K., 1776, Pieśni sobie śpiewane, Wilno.

Biblia w przektadzie Jakuba Wujka z 1599 r., transkrypcja typu B oryginalnego tekstu z XVI w., 1999, wstępy J. Frankowski, Warszawa.

Chachulski T., 1995, „Hej gdybym stworzyć hymn zdołała nowy!”. O „Pieśniach sobie śpiewanych" Konstancji Benisławskiej, w: Motywy religijne w twórczości pisarzy polskiego oświecenia, red. T. Kostkiewiczowa, Lublin, s. 77-92.

Gomola A., 2009, Jakim ojcem jest Bóg? Konceptualizacja Boga jako Ojca, w: Język religijny dawniej i dziś (w kontekście teologicznym i kulturowym) materiaty z konferencji, Gniezno 22-24 września 2008, red. P. Bortkiewicz, S. Mikołajczak, M. Rybka, Poznań, s. 207-313.

Gorzelana J., 2006, Perswazyjność, w: tejże, Właściwości językowo-stylistyczne poezji religijnej Franciszka Karpińskiego, Zielona Góra, s. 190-218.

Gorzelana J., 2011, Funkcja zdrobnień w Pieśniach sobie śpiewanych Konstancji Benisławskiej, w: Język pisarzy. Problemy stownictwa, red. T. Korpysz, A. Kozłowska, Warszawa, s. 285-307.

Gorzelana J., 2012, Leksyka odnosząca się do anioła w „Pieśniach sobie śpiewanych” Konstancji Benistawskiej, w: Język doświadczenia religijnego, t. 4, red. G. Cyran, E. Skorupska-Raczyńska, Szczecin, s. 91-112.

KKK - Katechizm Kościoła Katolickiego, 1994, Poznań.

Pawlikowska A., Język religijny na tle stylów funkcjonalnych polszczyzny pisanej - analiza porównawcza z perspektywy statystycznej, „Rozprawy Komisji Językowej WTN” XL: 2013, s. 55-73.

Rutkowska I., 2005, „, Umieram, bo nie umieram”- paradoks w wypowiedziach mistyków, w: Język religijny dawniej i dziś. Materiaty z konferencji Gniezno 3-5 czerwca 2004, red. S. Mikołajczak, T. Węcławski, Poznań, s. 518-527.

SL - Linde S.B., 1807-1814, Stownik języka polskiego, t. 1-6, Warszawa.

Zaręba A., 1956, Nazwy barw w dialektach i historii języka polskiego, Wrocław. 